\title{
COMPETITIVENESS OF UKRAINIAN SEAMANS AT THE MODERN LABOR MARKET
}

\author{
Andrey Lisiy \\ Department of Navigation and handling ship \\ Azov Maritime Institute of National University "Odessa Maritime Academy" \\ 19 Chernomorskaya str., Mariupol, Ukraine, 87517 \\ anlis@ami.edu.ua \\ Vitaliy Kotenko \\ National University "Odessa Maritime Academy" \\ 19 Chernomorskaya str., Mariupol, Ukraine, 87517 \\ dogyua@gmail.com
}

\begin{abstract}
The article considers the study of the modern maritime labor market, comparison and analysis of education systems, number of seamen by nationality at the trade fleet. As a result of the presented statistical analysis, there can be seen the stable growth of a number of Asian seamen and slow, but stable fall of a percent of seamen from Europe. The analysis of the maritime labor market the last years demonstrates the small growth of a number of European seamen, but the fall in percent ratio to the previous years, connected with the world growth of the trade fleet. The development of the market of maritime labor and the dynamics of changes at it mainly depend on external and internal factors. State standards of training seamen and requirements to their professional competence must be constructed taking into account national and international requirements. An important external factor that influences the development of professional training of qualified seamen is the demand of shipowners for specialists that correspond to requirements of the convention and Code of STCW. Main problems, connected with education and training of future seamen, remained from the times of USSR, and are traced for today also. For solving them, under conditions of fast re-orientation from the internal market to the external one, at absence of the modern Ukrainian fleet, cardinal changes are necessary in the system of education for raising the competitiveness at the labor market, necessity of a state intervention in this question for increasing the material base, control, inflow of young specialists with the modern experience of working in this field.

The modern maritime Ukrainian doctrine includes main directions, according to which elaboration of program documents is realized, namely the development of education in the maritime field. At the same time, it is noted that "the state system of providing safety of navigation may become an effective instrument of solving tasks of the state maritime policy under conditions of functioning such main components of it as: a system of training and retraining of specialists for the maritime field and also organizations and enterprises that realize the activity on providing navigation safety" [1]. As an example, there is considered financing of scientific studies and training of seamen at Szczecin (Poland). The improvement of the modern training system is a necessity and must include a complete synergy of three main directions: theoretical knowledge, practical knowledge and English. The following labor market requirements to modern specialists in a perspective may be the following ones:

- at the theoretical level - scientific thinking, formation of knowledge of management and marketing, ecological and legal knowledge;

- at the practical level - commercial knowledge; ability to work in a collective competence; perfect mastering of informational and communicational technologies; mastering of foreign languages and so on;

- at the personal level - social competence; communication skills; personal initiative; responsibility; professional mobility; individuality; competitiveness; creativity; ability to make correct decisions; fast adaptation to changes [2]..

Keywords: maritime labor market, competiveness of seamen, training of seamen, percentage of Ukrainian seamen at the labor market.
\end{abstract}

\section{Introduction}

The maritime labor market changes rather dynamically the last years. Standards of training seafarers grow annually, especially taking into account the fact that the main cause of emergency situations remains a human factor. Ukraine occupies the sixth place in the world at the maritime labor market and according to the data of Manpower Report [3] has near 39000 of officers and 30000 of ratings. 
The last years the share of Asian seamen essentially grows that must influence our positions at the market. It is already evident for ratings, who has more and more difficulties with finding a job and being competitive. The main problems of it are the quality of professional training and English level. For not losing their positions and even for strengthening them in future, the whole Ukrainian maritime sector must be united and be ready to changes. The Ukrainian state must deeply change its attitude to its role in this question.

Year by year Ukraine becomes an unalienable part of the European society. But we can now see a tendency, when European shipowners prefer their compatriots from EU in key positions at ships, and also have quotes for workers from EU, that Ukraine is not a member of for today, that also complicates Ukrainian seafarers' lives.

It must be remembered that Ukraine has not ratified the Convention MLC 2006 yet, and no one knows, when it does it. Foreign shipowners are mainly interested in selecting seamen from country-members of MLC 2006, but main problems remain - training level of both officers and ratings, and English level. According to the last report of Manpower Report [3], Ukraine occupies the $6^{\text {th }}$ place at the maritime labor market (Fig. 1), but first places are occupied by Asian countries and taking into account the dynamic development of their market of maritime traffic, it must be expected that their destination at the market will have the dynamics of growth and Ukrainian seamen must propose anything to shipowners for not losing their positions.

\begin{tabular}{|c|c|c|c|c|c|}
\hline No. & country & $\begin{array}{c}\text { total officers and } \\
\text { ratings }\end{array}$ & officers & ratings & $\begin{array}{c}\% \text { of the total } \\
\text { number }\end{array}$ \\
\hline 1 & China & 243635 & 101600 & 142035 & 14,78 \\
\hline 2 & Philippines & 215500 & 72500 & 143000 & 13,08 \\
\hline 3 & Indonesia & 143702 & 51237 & 92465 & 8,72 \\
\hline 4 & Russia & 97061 & 47972 & 49089 & 5,89 \\
\hline 5 & India & 86084 & 69908 & 16176 & 5,22 \\
\hline 6 & Ukraine & 69000 & 39000 & 30000 & 4,18 \\
\hline 7 & Turkey & 38985 & 18568 & 20417 & 2,36 \\
\hline 8 & Malasia & 35000 & 6313 & 28687 & 2,13 \\
\hline 9 & Italy & 34486 & 12988 & 21498 & 2,09 \\
\hline 10 & Norway & 33701 & 14768 & 18933 & 2,06 \\
\hline
\end{tabular}

Fig. 1. Countries-suppliers of seafarers for the labor market

15 of November of 2017 in Odessa there took place the conference of "Ukrainian crewing the role of quality of training seamen and development of being busy under conditions of competitiveness at the world labor market". At which a director of UOCC, a captain Viacheslav Kislovsky noted that the exclusion of Ukrainian specialists of young contingent has already become permanent [4]. Shipowners want to employ representatives of other nationalities. And it is not a problem of nationality as such, but a level of training and quality of the staff, in the first turn. He also stressed a necessity to make a close interconnection between maritime educational institutions, centers of training maritime specialists, Ukrainian crewing as a mediator between a seaman and a shipowner.

It is not enough, but, first of all, it must involve the state that, in fist turn, doesn't participate in a Ukrainian seaman life, and sometimes interferes with it. The training system must be reviewed to align it with higher standards, needed by the modern labor market.

It is necessary to note the problem of all post-soviet countries, when after disintegration of the Soviet Union, a state and maritime institutions in short term must re-orient on the new labor market that differed from the soviet one [5]. Fast reorientation has negative results in the training system that can be seen till now.

Training of modern specialists is realized by learning separate academic subjects. A disadvantage of this training is in absence of the close connection between knowledge of separate subjects and their practical use [6]. The quality of training is determined by the actual use of the complicated ship technique by a specialist in the volume, needed for own level, ability to solve different and complicated tasks under dynamic conditions that continuously change, to be able to 
obtain and analyze diverse information from different technical means, to use on practice methods of providing safety different by nature. For this aim we must take interconnection at the principally new level, not only between different subjects, but between theoretical and practical parts of training. It relates to both command and ratings.

\section{Aim}

Determination and analysis of dynamics and uncertainty at the maritime labor market that actualizes in a human the need to obtaining the quality professional training at the level of international recognition for employment at ships of both national and international companies, and also main factors that influence the competitiveness of Ukrainian seafarers.

\section{Research material}

Despite the fact that most shipowners begin to use more and more shortened crews, a demand for officers remains high, although their number grows fast (Fig. 2), as opposite to ratings that is enough (Fig. 3).

\begin{tabular}{|c|c|c|c|c|}
\hline & 2005 & 2010 & 2015 & 2017 \\
\hline officers & 466000 & 624000 & 774000 & 835400 \\
\hline ratings & 721000 & 747000 & 873500 & 904000 \\
\hline total & 1187000 & 1371000 & 1647500 & 1739400 \\
\hline
\end{tabular}

Fig. 2. Total number of seamen in the world trade fleet, 2005-2017

\begin{tabular}{|c|c|c|c|}
\hline & officers & ratings & total \\
\hline supply & 835400 & 904000 & 1739400 \\
\hline demand & 849000 & 774000 & 1623000 \\
\hline balance & 14000 & 130000 & 116000 \\
\hline$\%$ & $1,90 \%$ & $14,40 \%$ & $6,60 \%$ \\
\hline
\end{tabular}

Fig. 3. Balance of demand and supply of seamen in 2017

According to BIMCO/ICS prognoses, the deficit of officers for the trade fleet till 2025 will reach near 150 thousand persons, and Ukrainian seamen will have a possibility to strengthen their positions at the international labor market. But at the moment we lose this competition.

Our seafarers lose a competitive fight for working places to more trained staff, or to cheaper ones. The fact that Asian seamen will begin to supplant Ukrainian ones from the labor market was almost impossible for us, but we can see this process almost today, even in companies, where Ukrainian have worked for years. At the beginning we were supplanted from the level of ratings, today it is felt even at the officers level market. The dynamics of these changes doesn't provide stability at the labor market for Ukrainian seamen.

Training of officers and ratings in Asian countries (China, Philippines, Indonesia, India) is dynamic and in the nearest future, if a situation doesn't change, we can lose our positions (Fig. 4, 5). Attention must be paid also to UNCTAD data for 2015-2017, the trade fleet grew from 90470 to 93262 that was almost $1.5 \%$ per year.

Annually Ukrainian maritime educational institutions graduate thousands of navigators and engineers, but their professional skills don't always correspond to high standards of the modern labor market. Young staff, having come at a ship after studying or at it, has only surface and outof-date information about what happens under real conditions of ships. Obtained knowledge are not always supported by practice, in simpler words, they didn't ever touch any modern equipment by their hands, and have no complete understanding of standard safety procedures and court documents that they must cope with everyday.

As it is considered by a managing director of a company "CMA CGM, Ukraine" [7], main problems at employing Ukrainian seafarers are the low English level, banal lack of experience and unprofessional attitude to own work, manifested in repeated cases of excess alcohol taking and decrease of motivation after making a contract. "Young officers are denied in first turn because of the low level of training at educational institutions: because of total corruption, a mean point doesn't reflect real knowledge of a graduate. Finally, the very high priority of money also plays its 
role: many officers are ready to change companies permanently for a minimal bonus to a salary. So, a shipowner must completely deny the concrete nationality and to choose more loyal officers".

\begin{tabular}{|l|c|c|c|c|}
\hline \multirow{2}{*}{ Developing countries } & \multicolumn{4}{|c|}{$\mathbf{2 0 0 5}$ year } \\
\cline { 2 - 5 } & officers & $\%$ & ratings & $\%$ \\
\hline Eastern Europe & 133000 & $28 \%$ & 174000 & $19 \%$ \\
\hline Africa and Latin America & 95000 & $20 \%$ & 115000 & $15 \%$ \\
\hline Far East & 38000 & $8 \%$ & 110000 & $15 \%$ \\
\hline Indian subcontinent & 133000 & $28 \%$ & 226000 & $37 \%$ \\
\hline Totally & 68000 & $15 \%$ & 96000 & $14 \%$ \\
\hline & 467000 & $100 \%$ & 721000 & $100 \%$ \\
\hline Developing countries & \multicolumn{4}{|c|}{$\mathbf{2 0 1 5}$ year } \\
\hline Eastern Europe & officers & $\%$ & ratings & $\%$ \\
\hline Africa and Latin America & 176000 & $23 \%$ & 118000 & $14 \%$ \\
\hline Far East & 135000 & $17 \%$ & 125000 & $14 \%$ \\
\hline Indian subcontinent & 65000 & $8 \%$ & 82000 & $9 \%$ \\
\hline Totally & 300000 & $39 \%$ & 477500 & $55 \%$ \\
\hline & 98000 & $13 \%$ & 71000 & $8 \%$ \\
\hline Developing countries & 774000 & $100 \%$ & 873500 & $100 \%$ \\
\hline Eastern Europe & & $\mathbf{2 0 1 7}$ year & \\
\hline Africa and Latin America & 184600 & $22 \%$ & 106800 & $12 \%$ \\
\hline Far East & 143000 & $17 \%$ & 127000 & $14 \%$ \\
\hline Indian subcontinent & 70400 & $8 \%$ & 76400 & $8 \%$ \\
\hline Totally & 333400 & $40 \%$ & 527800 & $58 \%$ \\
\hline
\end{tabular}

Fig. 4. Comparison of number of seamen at the trade fleet for 2005-2017

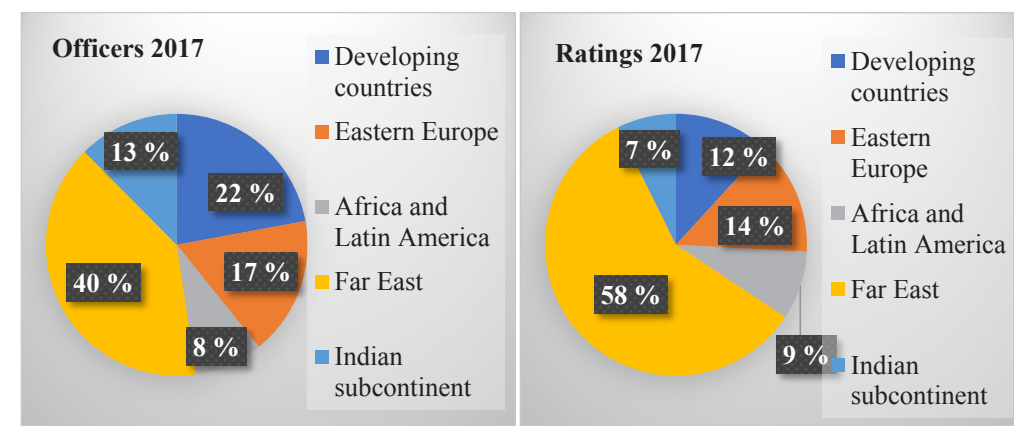

Fig. 5. Share of ratings and officers at the labor market

Considering insufficiency of practical experience at teaching, one must see a problem root. At the present stage we have no material base like in European HEIs, our seamen have no possibility to acquire full-value practical skills on using the modern equipment at educational institutions, including navigation devices and so on. For example, in Szczecin students have a possibility to fully master several types of radars, AIS, practice at several types of ECDIS at training of navigators. Graduates of European educational institutions usually have a sufficient level of knowledge as to main maritime conventions, such as SOLAS and MARPOL.

If compare the training system of students in Poland and Ukraine, in first turn, one may pay attention to the material part. Poland authorities and European Union give rather big resources not only for the training process, but also for scientific researches, that, it its turn, stimulates the development of the whole branch (Fig. 6). For last 18 only this educational institution realized over 50 projects that 1500000 and 74000000 zloty were received for. During education, already from the first year, students have a possibility to get into a working maritime vessel, to realistic conditions that they will cope with in future with, already from the first year.

At the first year students have a possibility to gain practice knowledge at $\mathrm{m} / \mathrm{v}$ «Nawigator XXI» with all necessary equipment. At the second learning stage students get into ferries of «PolishBalticFerry». The second most maritime institution of Poland - «Akademia Morskaw Gdyni» also has own ships for maritime practice that don't simply stay at port, but make real maritime voyages. Un- 
der these conditions students have a possibility to gain real practical skills of watchkeeping, dock operations, work of ship devices and so on. Even their colleges from Belgium that have no own ships for maritime practice use Polish ships for giving Belgian students and their teachers more practical experience. Unfortunately, our students have not such a possibility.

\begin{tabular}{|c|c|c|c|c|c|}
\hline 0. & Project name & Value & Source & \multicolumn{2}{|c|}{ Project duration } \\
\hline & $\begin{array}{l}\text { MORGRAV - Development of technology for acquisition and } \\
\text { exploration of gravimetric data of foreshore and seashore of } \\
\text { Polish maritime areas }\end{array}$ & $\begin{array}{l}729875,00 \\
\text { PLN (zloty) }\end{array}$ & $\begin{array}{l}\text { Program } \\
\text { Operacyjny } \\
\text { Inteligentny } \\
\text { Rozwój }\end{array}$ & 02.07 .2018 & 01.07 .2021 \\
\hline & $\begin{array}{l}\text { SARA-Maritime Search And Rescue solution using High } \\
\text { Accuracy EGNSS }\end{array}$ & $\begin{array}{l}129050,00 \\
\text { EUR (euro) }\end{array}$ & Horizon 2020 & 01.02 .2018 & 31.01 .2020 \\
\hline & EUFAL - Electric urban freight and logistics & $\begin{array}{l}201250,00 \\
\text { EUR (euro) }\end{array}$ & Era Net & 01.01 .2018 & 31.05 .2020 \\
\hline & $\begin{array}{l}\text { SOUTH COAST BALTIC-Establishing durable cross-border } \\
\text { boating destination management on the basis of the } \\
\text { MARRIAGE cooperation network }\end{array}$ & $\begin{array}{l}113053,00 \\
\text { EUR (euro) }\end{array}$ & South Baltic & 01.10 .2016 & 30.09 .2019 \\
\hline & $\begin{array}{l}\text { SBOIL - South Baltic Oil Spill Response through clean-up } \\
\text { with Biogenic Oil Binders }\end{array}$ & $\begin{array}{l}350250,00 \\
\text { EUR (euro) }\end{array}$ & South Baltic & 01.07 .2016 & 30.06 .2019 \\
\hline & Low Carbon Logistics & $\begin{array}{l}172600,00 \\
\text { EUR (euro) }\end{array}$ & South Baltic & 01.06 .2016 & 31.05 .2019 \\
\hline & $\begin{array}{l}\text { Go LNG LNG - Value chain for clean shipping, green ports } \\
\text { and Blue growth in Baltic Sea Region }\end{array}$ & $\begin{array}{l}320000,00 \\
\text { EUR (euro) }\end{array}$ & $\begin{array}{l}\text { Baltic Sea } \\
\text { Region }\end{array}$ & 01.05 .2016 & 30.04 .2019 \\
\hline & $\begin{array}{l}\text { MARELITT Baltic - Reducing the impact of marine litter in } \\
\text { the form of derelict fishing gear (DFG) on the Baltic Sea } \\
\text { environment. }\end{array}$ & $\begin{array}{l}225500,00 \\
\text { EUR (euro) }\end{array}$ & $\begin{array}{l}\text { Baltic Sea } \\
\text { Region }\end{array}$ & 01.03 .2016 & 28.02 .2019 \\
\hline & $\begin{array}{l}\text { EnviSum - Environmental Impact of Low Sulphur Ship Fuel: } \\
\text { Measurements and Modeling Strategies }\end{array}$ & $\begin{array}{l}349375,00 \\
\text { EUR (euro) }\end{array}$ & $\begin{array}{l}\text { Baltic Sea } \\
\text { Region }\end{array}$ & 01.01 .2016 & 28.02 .2019 \\
\hline & Total & $\begin{array}{l}729875,00 \\
\text { PLN (zloty) } \\
1861078,00 \\
\text { EUR (euro) }\end{array}$ & & & \\
\hline
\end{tabular}

Fig. 6. Current researches of the Szczecin maritime academy

There is a close interconnection between three general aspects of training students: theoretical, practical bases and learning English. They exist as not separate components but a single whole. It has a great importance and gives a necessary result it future.

We need a more flexible system of training seafarers-beginners. We need our HEIs to maximally cooperate with crewing, shipowners and involve the state to this problem. For today at absence of the modern trade fleet in our country seafarers, HEIs and state must exert maximal efforts for interesting foreign shipowners. It is not enough simply to say that our seamen have the high professional level, it must be proved practically and not only once.

According to a newspaper «The maritime Telegraph" at the Eurasian maritime summit in Odessa they were representatives of the Japanese maritime labor union, unions of officers and ratings of Singapore and also representatives of Great Britain and Sweden. As a result of the summit, sides concluded a resolution, according to which, Japanese and other side favor Ukrainian to be employed at Japanese and Singapore ships. «I think that Japanese companies will support 
Ukrainian seamen. We also must involve more Japanese companies that want to cooperate with qualified Ukrainian seamen", - said a representative of the labor union of Japanese seamen Ysume Morita [15].

Requirements to seamen today are not deduced to good mastering of the own profession, but certain mastering of English. Reality is such that many shipowners have completely mixed crews. The level of English that Ukrainian seamen come at ships with, most often doesn't correspond even to minimal requirements and it causes many obstacles and danger, because communication between crew members is almost absent. This problem is urgent for both experienced seafarers and young generation. This problem is especially traced among ratings and engineers.

Ukrainian seafarers are highly appreciated as good specialists that are not afraid of difficult work, but when it deals with communication, there are a lot of problems. Just a human factor, when a person thinks that English is not needed for working in an engine room, cannot be excluded.

For solving this problem there is needed a system approach at all learning levels. For today just the Soviet training system, where English was not considered as a very important factor at training a seaman, so it was taught without necessary interaction, is traced in the teaching system (Fig. 7) It was understandable, because Soviet seafarers worked at soviet ships only, that all communication was in Russian at. The Soviet system, undoubtedly, has own advantages, it was not bad or ineffective. But the problem is that circumstances and requirements to seamen changed that made this system of professional training insufficiently efficient under modern conditions.

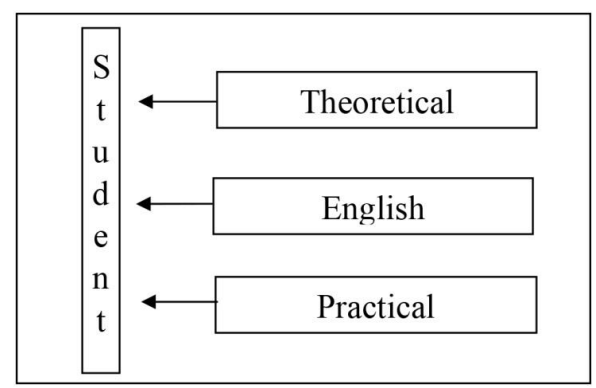

Fig. 7. Absence of interaction between main elements of training a seaman

As it demonstrated by the world practice, it is not effective to study these aspects, separately from each other. It must be distinctly understood, that a seamen specialty in our country is unalienably connected with foreign experience and language at absence of the modern Ukrainian fleet. The active participation of a state and synergy of all main training directions are necessary (Theoretical knowledge, practical knowledge and English) (Fig. 8).

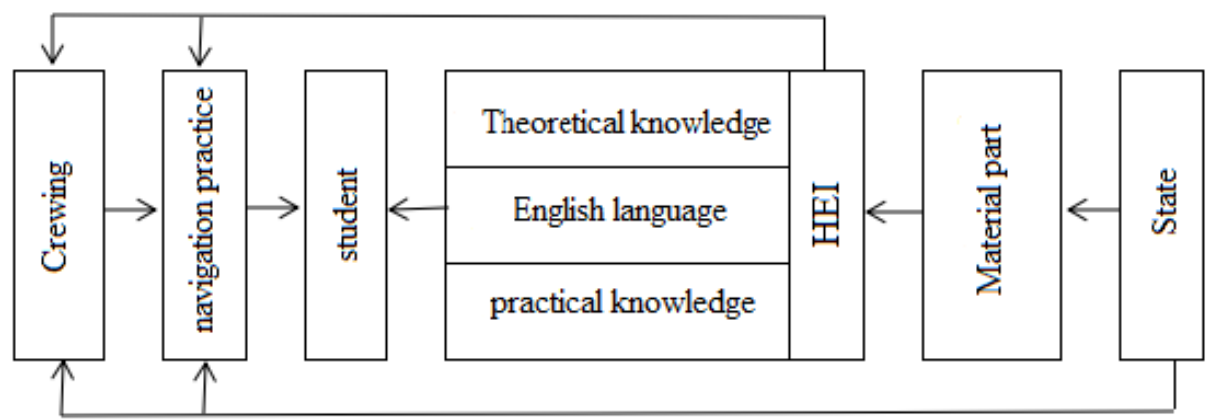

Fig. 8. Possible model of interaction between main training parameters

We must adopt the experience of our nearest neighbors, such as Poland or Romania. The English level of their seafarers is much higher, English is just a profile subject for them, and people begin to learn it at school. Even if we deal with Asian seafarers, even Filipinos, their English level is much higher among ratings than in us, at the same time they are less demanding to the conditions 
of contract, and are ready to work for much longer contract than Ukrainian seamen that give them advantages that we observe at the labor market for the last years.

For remaining competitive at the labor market, it is necessary to improve the level of professional training and control continuously, and also to take into account modern tendencies at training the staff. The educational process must include specialists that have information and practical knowledge as to the modern trade fleet.

But there is again the problem of material part, because many working seafarers are not ready to change a work in sea for one in a HEI, because a gap in salary is too much, and the state support is needed.

For example, we can consider Asian countries, where a salary of teachers of maritime HEIs is at absolutely another level, that, in its turn, attract more modern specialists in this field and already gives positive results. According to modern data, there are 70 thousand Indian officers as opposite to 39 thousand Ukrainian ones, and this difference only grows, based on a tendency.

\section{Research results}

At estimating the competitiveness of a Ukrainian seamen at the labor market, it is necessary to separate problems and perspectives of ratings and officers distinctly. If pay attention to ratings, the first role belongs to bad English, the other main problem is a banal lack of experience, the third place is a weak motivation and alcohol abuse. We must also remember that a rather big share of ratings was professionally trained by the Soviet system yet, and it must be understood, that in the nearest future younger specialists will replace them, and the lack of experience and knowledge will be more urgent. It underlines one more time that the problem must be solved complexly, but not in separate aspects.

As to officers, a situation is a bit different. The first place is there belongs to the lack of knowledge and experience, as opposite to ratings, but the problem with English also remains one of main ones, and occupies the second place. It is especially traced among engineers. The third point may be called "Jumpership", in simpler words, the problem is that already ordered members of the officer staff are ready to change companies permanently for a minimal bonus to a salary, that, in its turn, disturbs stability at ships. It may result in negative consequences for the whole national segment. As a result, a shipowner may use services of less demanding and more stable staff.

The system of training specialists must be reviewed, interaction between main educational directions must enter a new level.

The role of the state in this problem must be noted. If Ukraine wants to remain a maritime state, it is necessary to participate more actively in training, controlling and employing own seafarers.

\section{Conclusions}

Thus, for today Ukrainian seamen still rather attractive for foreign companies, but changes are necessary for not losing own positions at the labor market:

1) To change the attitude of seafarers to their work. It is even possible to agree for less attractive labor conditions for not to lose positions at all.

2) Educational institutions and state must elaborate principally new and modern methods of training both officers and ratings, corresponding to modern tendencies or even leave them behind.

3) To make all possible to attract modern specialists in this branch and to give them all necessary resources for working.

4) To stop underestimating the problem of English among Ukrainian seamen. It is necessary to intensify the control of learning English among Ukrainian seamen, and also to inform future specialists about its necessity and topicality at the modern fleet. Possibly it is necessary to elaborate a program of improving English among working seafarers at the state level. It is possible to adopt the experience of European countries, where many urgent problems are discussed and taught also in foreign language that improves further adaptation at real conditions at a ship.

5) To create full synergy in three main directions of training future specialists. 


\section{References}

[1] Morska doktryna Ukrainy na period do 2035 roku (2009). Postanova Kabinetu Ministriv Ukrainy 7.10.2009. No. 1307. Available at: http://zakon3.rada.gov.ua/laws/show/ru/1307-2009-\%D0\%BF

[2] Bidiuk, N. M. (2011). Kontseptualni zasady prohnostychnoho rozvytku systemy profesiinoho navchannia bezrobitnykh Ukrainy. Pedahohika i psykholohiia. Visnyk NAPN Ukrainy, 1 (70), 87-95

[3] The global supply and demand for seafarers in 2015 (2015). Manpower Repor. Available at: http://www.ics-shipping.org/docs/default-source/resources/safety-security-and-operations/manpowerreport-2015-executive-summary.pdf?sfvrsn=16 Last accessed: 07.09.2016

[4] Conference under the auspices of "VOKK" from 15.11.2017. Odessa. Available at: https://sudohodstvo.org/ukrainian-sea-labor-market-time-to-consolidate

[5] Tomilina, S. N. (2015). Features of training and education of cadets of marine universities in the post-Soviet republics. Scientific journal Kub GAU, 113 (9), 5-17.

[6] Pazynich, G. I. (2013). Some features of quality control of the training of navigators in modern conditions. Fisheries of Ukraine, 4.

[7] Special project: «shipowner leaders of crewing tell what to do to Ukrainian sailors in crisis» (2016). Seaworker. Available at: http://seafarers.com.ua/how-crisis-influences-jobs-availability-for-seafarers/8476/ Last accessed: 05.07.2016

[8] Gdynia Maritime School. Non-public training courses. Available at: http://morska.edu.pl/en/ page/196/start-page

[9] The world's largest international shipping association. Bimco. ICS manpower report predicts. Available at: https://www.bimco.org/

[10] Kosharskaya, L. V., Lyzina, T. A. (2017). Survey of maritime education in Ukraine. Development of management and entrepreneurship methods on transport, 4 (61), 77-87. Avaialble at: http://www. daemmt.odesa.ua/index.php/daemmt/article/view/179/149

[11] MAIB annual report (2016). Marine Accident Investigation Branch. Available at: https://assets. publishing.service.gov.uk/government/uploads/system/uploads/attachment_data/file/634809/MAIB_AnnualReport2016.pdf

[12] Corovic, B., Djurovic, P. (2013). Research of marine accidents hrough the prism of human factor. Promet - Traffic\&Transportation, 25 (4), 369-377. doi: http://doi.org/10.7307/ptt.v25i4.1210

[13] Global marine trends 2030. Available at:http://www.futurenautics.com/wp-content/uploads/2013/10/GlobalMarineTrends2030Report.pdf

[14] Maritime portal Safety4sea. Available at: https://safety4sea.com/

[15] Yaponiya i Singapur gotovy trudoustraivat' ukrainskikh moryakov (2018). Marine news portal. Available at: http://mtelegraph.com/japan-and-singapore-are-ready-to-employ-ukrainian-sailors.html Last accessed: 11.05 .2018

[16] The United Nations Conference on Trade and Development. Available at: www.unctad.org

[17] The European Maritime Safety Agency. Available at: http://emsa.europa.eu

[18] International and EU co-funded projects of the Maritime University of Szczecin. Available at: http://portalcttm.am.szczecin.pl/en/eu-projects

[19] Mindykowski, J., Charchalis, A., Przybylowski, P., Weintrit, A. (2013). Maritime Education and Research to Face the XXI-st Century Challenges in Gdynia Maritime University's Experience Part II - Gdynia Maritime University of Experience the 21st Century Challenges. TransNav, the International Journal on Marine Navigation and Safety of Sea Transportation, 7 (4), 581-586. doi: http://doi.org/10.12716/1001.07.04.14

[20] Cwilewicz, R., Lisowski, J. (2011). The Integrated Maritime Education and Research Activity of Gdynia Maritime University for Seafarers. The 12th Annual General Assembly of IAMU - green ships, eco shipping, clean seas, 87-98. Available at: http://iamu-edu.org/wp-content/uploads/2014/07/The-Integrated-Maritime-Education-and-Research-Activity-of-Gdynia-Maritime-University-for-Seafarers1.pdf

[21] Study supporting a possible network of maritime training academies and institutes in the Mediterranean Sea basin (2016). Available at: https://webgate.ec.europa.eu/maritimeforum/system/files/Maritime\%20Academies\%20-\%20Final\%20Report\%20and\%20annexes_template\%20EC_0.PDF

[22] Walczak, A. (2008). Participation of Polish Maritime Educational Institutions in Implementing Ideas of the EU Green Paper. International Journal on Marine Navigation and Safety of Sea Transportation, 2 (4), 429433. Available at: http://www.transnav.eu/Article_Participation_of_Polish_Maritime_Walczak,8,126.html 